Felipe Cárdenas

Instituto de Humanidades

Universidad de La Sabana

\title{
Crisis ambiental y cristianismo (1)
}

\section{INTRODUCCIÓN}

El deterioro de los recursos naturales es uno de los mayores problemas de la humanidad. La disminución de la calidad y cantidad de dichos recursos no solo es negativa por la destrucción del ambiente natural, sino porque merma, en todas sus expresiones y posibilidades, el potencial para impulsar un desarrollo humano sostenible, que responda a la justicia social y al clamor de los desposeídos de la tierra, representado por millones de hombres, mujeres y niños que carecen hoy de las mínimas condiciones para llevar una vida digna.

El ambiente natural, los paisajes culturales y la existencia de grandes unidades territoriales que permitan la vida de poblaciones vegetales, animales y humanas es el soporte físico-nuclear del desarrollo sostenible. La prosperidad del hombre y la erradicación de la pobreza están condicionadas por las relaciones armónicas que los sistemas culturales establezcan con el medio natural, que debe ser respetado, conocido y reconocido en todos sus procesos. El medio natural es una fuente de bienes y servicios para el desarrollo de la sociedad humana. El ambiente es un bien colectivo interdependiente y frágil. Si el medio natural se deteriora gravemente, como de hecho está sucediendo, no existe sistema económico, filosófico, religioso o cultural que pueda garantizar condiciones de vida justas y dignas para los seres humanos (2). Las dimensiones planetarias de la problemática ambiental hacen de dicha realidad uno de los temas y preocupaciones políticamente más relevantes de la actualidad. El tema es ineludible, cuando reconocemos que los principales responsables del origen del problema -en términos de su magnitud e impacto a escalas planetarias, son los países del primer mundo que comparten una tradición marcada por la influencia que

(1) Proyecto de investigación apoyado por el Fondo Patrimonial de la Universidad de La Sabana. El artículo se desprende del proyecto de investigación titulado "Narrativas ambientales andinas", perteneciente a la línea de investigación Identidades culturales, poder y narrativas contemporáneas del Grupo de investigación Vida política, orden y anomia social. Las opiniones del autor son independientes y libres, por tanto no expresan la posición oficial de la Universidad de La Sabana.

(2) Para ampliar el tema de la crisis ambiental y sus modelos científicos el siguiente artículo es una lectura complementaria al presente trabajo: Felipe Cárdenas, "Los silenciamientos de la ciencia ambiental: una reflexión crítica sobre estructuras de opresión", Nómadas, revista crítica de ciencias sociales y jurídicas, 16/2, 2007. 
ha ejercido el cristianismo en la configuración económica, política y cultural de Europa y Estados Unidos. Entonces, si estos países tienen una tradición cristiana, que expresa un mensaje de amor, esperanza, paz y justicia, ¿cómo es posible que la vida en la tierra esté amenazada como producto de unos estilos de vida anticristianos y antievangélicos?

La destrucción del planeta, un hecho real y objetivo, implica afinar y potenciar nuestra responsabilidad de salvaguardar el ambiente natural como patrimonio común de todo el género humano, incluidas las generaciones del futuro. ¿Tiene algo que decir el cristianismo sobre dicha problemática? Yo considero que el cristianismo, con una tradición milenaria tiene medios terapéuticos que pueden aportar en las curas que deben impulsarse para frenar la destrucción del territorio planetario, de los equilibrios naturales y de la diversidad biológica y cultural que se han configurado en la Tierra.

En las últimas tres décadas, diversos sectores públicos y privados a nivel mundial se han venido involucrando en la implementación de los principios y las acciones ligadas al desarrollo sostenible. Numerosas iglesias occidentales han manifestado su preocupación sobre el cambio climático, la destrucción de los sistemas ecológicos, y han enfatizado la necesidad de que el ser humano ejerza cuidado para toda la creación basado en la hermandad, el sacrificio y la caridad (3). Las comunidades religiosas, iglesias cristianas reformadas, la Iglesia católica y las iglesias ortodoxas, así como grupos no cristianos, han venido participando y contribuyendo cada vez más al debate ambiental. Los portales electrónicos de numerosas iglesias cristianas hacen menciones explícitas al tema ambiental. Su desarrollo ha sido tan importante que se ha venido constituyendo una forma teológica llamada ecoteología. Esta nueva visión o escuela teológica no es uniforme en sus desarrollos; sus principales exponentes pueden expresar sus preocupaciones en el marco de la más ortodoxa filosofía cristiana (4), o incluso manifestar sus posiciones discursivas en el horizonte de la nueva era y el neopaganismo (5).

En este artículo se analizará el papel del cristianismo en su dimensión ambiental buscando identificar elementos que nos permitan adquirir una mayor responsabilidad en la posible solución de la crisis ambiental que vive hoy la humanidad y reconocer posibles pautas de acción para la mitigación la misma (6). Se trabajará con base en algunos desarrollos bíblicos que son ideas-fuerza con las que cuenta el ser humano para comprender el sentido de la crisis y problemática ambiental. Como vehículo de la acción del cristianismo en un plano sociológico y territorial, se llama la atención sobre el papel de la parroquia en los aportes que puede proporcionar para configurar un paisaje más humano. Finalmente, se presentará el valor de la parro-

(3) Valery Votrin, "The Orthodoxy and sustainable development: a potential for broader involment of the Orthodox Churches in Ethiopia and Russia", Environment, Development and Sustainability, núm.7, 2005.

(4) Wolfhart Pannenberg, Antropología en perspectiva teológica, Salamanca, Sígueme, 1993/1983; Juan Pablo II, La ciencia para la supervivencia y el desarrollo (Discurso al seminario). En La Academia de las ciencias, 12 de marzo, 1999.

(5) Leonardo. Boff, Ética planetaria desde el gran sur, Barcelona, Editorial Trotta, 2001.

(6) Felipe Cárdenas, Antropología en perspectiva ambiental, Bogotá, Editorial Epígrafe-Universidad de La Sabana, 2007. Disponible en http://www.epigrafe.com/contenido/lib_detalle.asp?lib_id=112 
quia en la conservación de los bosques en Etiopía. Dicha tradición eclesial es inspiradora para conectar la idea ambiental, con la acción y la experiencia milenaria de una Iglesia apostólica que expresa una forma material de conectar conocimiento y acción. Se tiene que reconocer que la diversidad de expresiones cristianas y sus ricas tradiciones son un potencial para una humanidad doliente, que reclama de todos los cristianos modelos de vida y acción inspiradas en el evangelio, en las enseñanzas de los padres de la Iglesia, en el magisterio, y en la vida de tantos hombres y mujeres que han vivido una auténtica experiencia de Dios en sus vidas, tanto en lo personal como en lo comunitario.

\section{ASPECTOS PRELIMINARES DEL PROBLEMA}

En general, un común denominador del aporte de las religiones cristianas tiene que ver con su visión sobre las raíces de la problemática ambiental contemporánea: la premisa fundamental es que el problema ecológico es la expresión de una crisis moral y espiritual en el hombre. Ahora, las visiones sobre la articulación sociedadnaturaleza en el cristianismo, como en el catolicismo, así como en la ortodoxia, en las iglesias reformadas, como las iglesias evangélicas no son uniformes. Las intencionalidades propias de los diferentes carismas y visiones teológicas o escuelas se expresan como propuestas eclesiales absolutamente marcadas por una visión trascendental a-política, o por visiones políticas a-trascendentales (7). Las oscilaciones que se registran en el mundo cristiano pretenden ser excluyentes unas de otras. Yo creo que son enfoques complementarios que deben valorarse como parte del patrimonio del que disponemos los cristianos y la humanidad para enfrentar la grave crisis planetaria que experimentan inmensos sectores de la población mundial y que se acentuará en los próximos años (2008 al 2050) mediante sequías, hambrunas, colapso de ecosistemas y el etnocidio que viven muchos pueblos indígenas que expresan un estilo de vida ambientalmente sostenible e inspirador en el marco de modelos de producción alternativos a los dominantes.

En el campo católico las visiones sobre la naturaleza se han construido histórica y teológicamente con base en el predominio de determinadas escuelas teológicas y sus visiones de naturaleza. Por un lado, la naturaleza puede comprenderse como la expresión de un mundo caído por el pecado original, y su consiguiente expresión dualista, que separa lo material de lo espiritual. Por otro lado, se puede constatar que la naturaleza está relacionada con lo divino, convirtiéndose de tal manera en objeto de veneración y respeto. Finalmente, la naturaleza se ha pensado como espa-

(7) Las teologías políticas no trascendentales tienen un referente importante en la obra de Johann Baptist Metz, Dios y tiempo. Nueva teología política, Madrid, Editorial Trotta, 2007. Estas teologías son la version europea de las teologías de la liberación latinoamericanas. Entienden la iglesia como institución crítica de la sociedad. En el campo de las teologías trascendentales las expresiones más elaboradas las encontramos en los desarrollos teológicos de la Iglesia ortodoxa. Especialmente teólogos como J. Zizioulas, Eucaristia e regno di Dio, Magnano, 1996. Estas teologías, en algunas de sus versiones ortodoxas entienden la estructura canónica de la Iglesia no en función de las necesidades organizativas, sino como expresión de la estructura del reino escatológico de Dios, porque también él tiene su estructura. 
cio donde operan fuerzas sobrenaturales, que se plasman en toda la rica expresión de formas culturales ligada a la religiosidad popular de nuestros pueblos a lo largo y ancho del mundo.

La investigación sobre la relación sociedad-naturaleza en el cristianismo tiene diversas posibilidades teóricas: 1) la perspectiva posmoderna que expresa en su postulado básico la noción de naturaleza como discurso socialmente construido, que está sujeta a constantes negociaciones en el contexto de la vida social; 2) una perspectiva culturalista, que entiende al ser humano como un constructor de sistemas culturales de significado que expresan una cosmología; y 3) finalmente, una perspectiva ontológica que, partiendo del horizonte de la libertad humana, reconoce la existencia de principios axiológicos anteriores a toda realidad y experiencia, que se constatan en el horizonte de una revelación, y que deben orientar la vida del ser humano. Las primeras dos perspectivas surgen de la antropología cultural y los estudios culturales. La tercera perspectiva está más ligada a la teología escolástica y al desarrollo de la metafísica.

Ahora, el discurso mundial de tipo ecologista generalmente ignora el papel de la revelación cristiana o se constata una práctica abiertamente hostil a un reconocimiento de los valores del evangelio como un camino para superar la crisis planetaria. Dicha actitud debe entenderse como parte de las mentalidades ilustradas y emancipadas que la modernidad generó y que expresan una secularización exasperada de carácter nihilista. Afirmaciones como "Dios es Espíritu" (revelación del Salvador a la Samaritana, San Juan 4, 24), "El Señor es el Espíritu" (2 Cor. 3, 17), "Porque Dios es el Espíritu; y donde está el Espíritu del Señor, allí hay libertad" (2 Cor. 3,17 ), son expresiones que denotan una dimensión de la realidad que no tiene cabida en los ambientalismos materialistas que dominan el campo del pensamiento ecológico y ambiental. Las anteriores expresiones del evangelio manifiestan un componente ineludible de nuestra memoria sobre la realidad y la historia; son pilares para el conocimiento humano y la realización ética del hombre desde los horizontes del metadiscurso religioso. La naturaleza espiritual es ignorada, desconocida y violentada por la visión secularista dominante. Dicha mentalidad es muy poderosa como fuerza cultural, y tiene alianzas con el neopaganismo y un positivismo religioso postidealista, que minimiza el valor existencial, ontológico y trascendental de la Iglesia, como institución histórica y metahistórica. La crisis ambiental no puede entenderse al margen de las estrategias del mal que se expresan con violencia en la historia del hombre y que genera una crisis de la representación de la cual la teología de tradición latina ha sido víctima y victimario.

En los trabajos de Max Scheler, referidos al puesto del hombre en el cosmos, lo espiritual es un componente objetivo de la realidad y no simplemente un capricho de la mente humana: "Espíritu es por tanto, objetividad; es la posibilidad de ser determinado por la manera de ser de los objetos mismos. Y diremos que es sujeto o portador de espíritu aquel ser cuyo trato con la realidad exterior se ha invertido en sentido dinámicamente opuesto al del animal" (8). Ahora, Dios se expresa tanto de manera objetiva, como subjetiva, pero también su naturaleza no es ni objetiva, ni

(8) Max Scheler, El puesto del hombre en el cosmos, Buenos Aires, Losada, 1938, p. 56. 
subjetiva. Por un lado, el creyente o el no creyente pueden tener una experiencia positiva o negativa de Dios que puede captar desde una base subjetiva propia a cada individuo. Esa es una dimensión subjetiva de su experiencia de Dios. Por otro lado, Dios se reveló de manera muy clara en la historia del pueblo judío que sistematizó la expresión tanto objetiva como subjetiva de dicha comunicación divina en la Biblia. Los diversos autores sagrados, inspirados por el Espíritu Santo, no agotaron ni estaban en capacidad de transcribir, conocer o reconocer todo el poder, la energía ni la esencia de Dios. Dios está más allá de lo objetivo y subjetivo, ámbitos propios de la experiencia humana sobre la realidad.

\section{El dilema bíblico en el Antiguo Testamento}

Como ya es ampliamente conocido, en el año de 1967, el historiador norteamericano Lynn White Jr. publicó en la revista Science (9) un artículo titulado "The Historical Roots of our Ecologic Crisis". Con esta publicación "científica" se inició un candente debate a nivel mundial sobre el papel del cristianismo como motor de la crisis y problemática ambiental. Para este historiador, la raíz de la problemática ambiental contemporánea se explicaba debido a una supuesta actitud de arrogancia del cristianismo hacia la naturaleza. Desde esa fecha, se pueden ubicar dos campos de análisis bíblicos de cierta manera antagonistas. Por un lado, se encuentran los que entienden la cosmovisión bíblica como estrictamente tiránica y destructiva con respecto a la relación del hombre con la naturaleza. Consiguientemente, el cristianismo habría sido un promotor de la destrucción. Esta forma narrativa es característica del ethos de muchos grupos ecológicos que proclaman una noción del medio ambiente basada en el biocentrismo y el ecocentrismo que sacraliza en igualdad de condiciones al hombre y a todas las formas de vida. La abiótico y lo biótico son los elementos de una nueva religiosidad neopagana. Por otro lado, se encuentran quienes entienden que Dios hace responsable al hombre de su creación, otorgándole al ser humano una condición de regente iluminador en el proceso. El pasaje bíblico más citado en el marco del debate sobre el papel humano en sus relaciones con la naturaleza no humana está en Gen. 1, 26-28. Literalmente dice:

"Y dijo Dios: Hagamos al hombre a nuestra imagen, conforme a nuestra semejanza; y ejerza dominio sobre los peces del mar, sobre las aves del cielo, sobre los ganados, sobre toda la tierra, y sobre todo reptil que se arrastra sobre la tierra (Gen 1, 26). Creó, pues, Dios al hombre a imagen suya, a imagen de Dios lo creó; varón y hembra los creó (Gen 1,27). Y los bendijo Dios y les dijo: sed fecundos y multiplicaos, y llenad la tierra y sojuzgadla; ejerced dominio sobre los peces del mar, sobre las aves del cielo y sobre todo ser viviente que se mueve sobre la tierra (Gen 1,28)".

Para White, la brutal explotación técnica de que ha hecho objeto a la naturaleza el hombre occidental se debe a la funesta influencia del nexo judeocristiano entre

(9) Lynn White, "The Historical Root of our Ecological Crisis”, Science, núm. 7, 1967. 
el destino del hombre a semejanza con Dios y la misión de dominio y sojuzgamiento de la naturaleza. Desde 1967 se ha discutido ampliamente sobre el tema (10). El desenlace del debate ha superado, en los estudios más profundos, la visión simplista y estereotipada que formulara White. Algunos pensadores consideran que ya no se trata tanto de culpabilizar al judeocristianismo sino a la civilización grecolatina (11). Otros estudiosos, como Jeanne Kay (12), plantean la necesidad de analizar e interpretar la Biblia desde una perspectiva sincrónica, esto es, a partir de la comprensión de ella como un trabajo de literatura antigua y, adicionalmente, interpretarla desde una perspectiva geosófica; es decir, entenderla a partir de las propias perspectivas existentes en la edad de hierro. Muchos de los pensamientos teológicos modernos provenientes de la apologética cristiana, abren el camino para una nueva resacralización de la naturaleza. Por ejemplo, para John Cobb, uno de los más destacados teólogos norteamericanos, la situación mundial exige del cristiano más responsabilidad hacia la conservación de la naturaleza (13). Solo a partir del siglo XVIII, cuando el hombre moderno, en su autocomprensión, se desvincula del Dios creador bíblico, es cuando el mandato divino de Gen 1-26:28 se interpretó como la justificación para poder disponer y explotar ilimitadamente de la naturaleza. Evidentemente esto sucedió en el seno de una civilización de raíces cristianas, que experimentó un proceso histórico y cultural caracterizado por la ruptura del orden trascendente, la desacralización acelerada de la naturaleza y del orden cultural. Pero como nos dice Pannenberg,

"es injusto achacarle globalmente a la cristiandad occidental esta perversión del encargo bíblico y el desconocimiento de la función de delegación y representación que comportaba. Ha sido solo la emancipación del hombre moderno de la revelación bíblica la que ha convertido el encargo bíblico en un sentimiento plenipotenciario de la naturaleza para ser usada a capricho" (14).

Evidentemente, el debate, como nos indican Sherkat y Ellison (2007), ha generado toda una línea de investigación que se articula alrededor de las conexiones entre religión y ambiente: se hace pertinente identificar las influencias de doble vía entre religión, preocupación ambiental y grado de influencia que tiene lo religioso sobre el ambiente y viceversa. El estudio de Sherkat y Ellison indica cómo a pesar de la gravedad de la crisis ambiental, muchos sectores en las iglesias evangélicas conservadoras - pro Bush- de Estados Unidos se niegan a reconocer que la actual

(10) Felipe Cárdenas, "Los silenciamientos de la ciencia ambiental: una reflexión crítica sobre estructuras de opresión", Nómadas, Revista Crítica de Ciencias Sociales y Jurídicas, Universidad Complutense de Madrid, vol. 16, núm. 2, 2007; Felipe Cárdenas, Antropología en perspectiva ambiental, Bogotá, Editorial Epígrafe-Universidad de La Sabana, 2007; D. Eherenfeld, y B. Philip, Judaism and the practice of Stewardship, Judaism, vol. 34, 1985; S. Schwarzschild, "The Unnatural Jew", Environmental Ethics, núm. 6, 1984.

(11) J. Passmore, Man's responsibility for Nature: Ecological Problems and the Western Traditions, New York, Charles Scribner and Sons, 1974.

(12) J. Kay, Concepts for Nature in the Hebrew Bible, Environmental Ethics, vol. 10, núm. 4, 1988.

(13) Ver Pannenberg, ob. cit., 1993, p. 96.

(14) Ibíd., p. 97. 
crisis planetaria tiene que implicar un compromiso serio por parte del hombre (15). El reciente trabajo de Sherkkat y Ellison (16) señalan cómo en Estados Unidos todavía hay sectores de la población cristiana que no creen que el problema ambiental sea algo serio. Asimismo, tampoco están interesados en sacrificarse por el medio ambiente.

En el centro del debate se encuentra el cristianismo, ya sea como propiciador o como agente de solución a la crisis mundial. Per Binde (17) recalca cómo la cosmología cristiana es dualista y expresa una dicotomía entre la mente y la materia. Según él, esta dicotomía se originó en la filosofía griega, tanto Aristóteles como Platón utilizan categorías dualistas. En Platón, la distinción entre el alma, de origen divino, y el cuerpo, asiento de lo demoníaco, es muy marcada. La Iglesia ha enseñado que el mundo material y mundano no debe ser el eje del accionar de la persona. Por un largo periodo de tiempo, y hasta el siglo XVIII, una de las perspectivas cristianas de naturaleza fue la de asociarla con lo material en el horizonte de una perspectiva negativa (18). Tocaría evaluar si existe pueblo en la tierra, que en su cognición sobre el mundo, haya alguna vez superado del todo el dualismo como construcción lingüística. La separación de identidades y la diferenciación entro lo humano y lo no humano, arriba y abajo, macho y hembra es una constante en la experiencia humana, a la que no le queda otra alternativa sino la diferenciación. No debe sorprendernos que la creación de la naturaleza en la visión bíblica, como estado prístino se juzgara como "buena en gran manera" (Gen 1, 31) o maldita en otros momentos. Por comer del árbol prohibido, Dios castigó a la Tierra: "maldita será la tierra por tu causa; con trabajo comerás de ella todos los días de tu vida. Espinos y abrojos te producirá, y comerás de las plantas del campo" (Gen 3,18). "Con el sudor de tu rostro comerás el pan hasta que vuelvas a la tierra, porque de ella fuiste tomado; pues polvo eres, y al polvo volverás" (Gen 3, 19). Otro pasaje que explica la presencia del mal y la maldición de la Tierra por acción de Dios, debido a la maldad humana, se refiere a la maldición de Dios a Caín, que se expresa en deterioro del suelo: "Cuando cultives el suelo, no te dará más su vigor; vagabundo y errante serás en la tierra" (Gen 4,12). El diluvio universal es el otro episodio que expresa la acción de Dios como respuesta a la corrupción y maldad en el hombre:

(15) Darren Sherkat y Ellison Christopher, "Structuring the Religión-Environment Connection: Identifying Religious Influences on Environmental Concerning and Activism", Journal for the Scientific Study of Religión, vol. 46, núm 1, 2007, pp. 71-85.

(16) Darren Sherkat y Christopher Ellison, "Structuring the Religión-Environment Connection: Identifying Religious Influences on Environmental Concern and Activism", Journal for the Scientific Study of Religión, vol. 46, núm. 1, 2007.

(17) Per Binde, 2001.

(18) La teología de santo Tomás de Aquino (1224-1274), con base en su soporte aristotélico, enfatizará que existe un propósito natural en todas las cosas. En el mundo opera una jerarquía, que implica que las formas de vida menores deben organizarse en función de las mayores. Santo Tomás escribió: “...la vida de los animales y plantas está dada (subsiste) no para ellas, sino para el hombre". Animales y plantas sirven al hombre y el hombre sirve a Dios. Durante el Renacimiento, esta noción de estricta dominancia jerárquica, en donde Dios es superior al hombre y el hombre superior a la naturaleza, hizo parte de los desarrollos intelectuales de pensadores como Masilio Ficino (1433-1499) y Giovanni Pico della Mirandola (1463-1494). 
"Y el Señor vio que era mucha la maldad de los hombres en la tierra, y que toda intención de los pensamientos de su corazón era solo hacer siempre el mal. Y le pesó al Señor haber hecho al hombre en la tierra, y sintió tristeza en su corazón. Y el Señor dijo: borraré de la faz de la tierra al hombre que he creado, desde el hombre hasta el ganado, los reptiles y las aves del cielo, porque me pesa haberlos hecho (Gen 6, 5-7)".

El pecado original es un estado, mas no la naturaleza del hombre, hecho a imagen y semejanza de Dios; como estado humano se irradia en toda la Tierra. Los pensadores cristianos, como los judíos, han creído que la Tierra fue hecha perfecta y con elementos naturales armoniosos. La armonía se perdió por el comportamiento de Adán, Eva, Caín... La perversión del individuo tiene resonancia planetaria. En esta perspectiva, la relación sociedad-naturaleza es pesimista. En pactos posteriores, Dios incluso es más enfático sobre el poder del hombre y su accionar en la Tierra:

"Y bendijo Dios a Noé y a sus hijos, y les dijo: sed fecundos y multiplicaos, y llenad la tierra. Y el temor y el terror de vosotros estarán sobre todos los animales de la tierra, y sobre todas las aves del cielo, y en todo lo que se arrastra sobre el suelo, y en todos los peces del mar; en vuestra mano son entregados (Gen 9,1-2)".

También encontramos perspectivas más optimistas, que incluso son hoy los discursos más dominantes en la Iglesia Católica Romana, donde ya no se enfatiza tanto sobre el dominio del hombre sobre la naturaleza. Estas posiciones entienden que el dominio del hombre sobre la naturaleza tiene que contener elementos morales y estar cimentado sobre la razón y el respeto. La naturaleza se entiende como vulnerable; no es insensible a la destrucción que ejerce el hombre sobre el planeta. La naturaleza es una parte de la creación de Dios, objeto de alabanza ( Sal 104, 24) y en abierta relación a un proyecto salvífico ligado al mundo y a la historia. (cf. Is 65, $17 ; 66,22 ;$ Ap 21,1$)$ y basado en la justicia $(2 \mathrm{P} 3,10)$.

Existe toda una filosofía de la naturaleza, desarrollada por teólogos como san Agustín y Hugo de san Víctor. Estos desarrollos teológicos tienen su fuente en las enseñanzas del apóstol Pablo (Rom 1, 20). San Buenaventura argumentó que el hombre era un intérprete de la creación; la contemplación de las cosas visibles y tangibles de la naturaleza eran una vía para el viaje místico, a través de los seis estadios de la iluminación que culminarían en la unión con Dios. En su controversia contra la herejía catara, que estaba fundamentada en una creencia marcada por un dualismo radical entre el bien y el mal, la Iglesia Católica se vio obligada a enfatizar la bondad de la creación material. La Orden de Santo Domingo estuvo al frente de esta batalla, afirmando que la naturaleza era buena y, por tanto, una prueba de la bondad de Dios.

Desde los primeros tiempos cristianos, y también en la tradición judía, el desierto y la naturaleza, han tenido un profundo significado. La vida de Juan el Bautista, viviendo pobremente y predicando en el desierto, ha sido un modelo ejemplificante para anacoretas, monjes y comunidades religiosas, tanto cristianas como judías. Jesús era judío y no cristiano. Y hablo mucho más de la Iglesia que del cristianismo. 
El cristianismo, como producto del judaísmo y de la civilización grecolatina ha asociado el bosque silvestre con la presencia de lo divino y sagrado. Desde los primeros tiempos cristianos, miles de monasterios se han construido en parajes solitarios y en montañas remotas. Sus protagonistas han sido hombres y mujeres que han huido del mundo, del ruido y la perdición de las ciudades. La posibilidad de un paraíso acá en la Tierra ha estado asociada a la campiña y a la vida rural. El hombre como ser creado, cuando es tocado por Dios y se convierte, establece un intento por volver a la plenitud de su identidad humana. La adquisición de la plenitud, en muchos casos y experiencias de vida, ha tenido como soporte el huir del mundo, para refugiarse en las fronteras solitarias del universo creado.

En el contexto mencionado, el mandato de Gen 1-26-28 se comprende en la exégesis contemporánea como la expresión del sociomorfismo, propio de la época pastoril en la que vivían los israelitas; esto lleva a evidenciar el precepto administrativo, de manejo y cuidado de la naturaleza, y ha advertir que dichos pasajes bíblicos no autorizan al ser humano a comportarse antiecológicamente. La sentencia bíblica formula un reto para el mundo de hoy. No desconoce la dignidad del hombre, pero tampoco es precepto de destrucción. El explícito mandato divino de dominar sobre la naturaleza no significa una autorización para expoliar a la naturaleza no humana y aprovecharla de manera egoísta.

Es importante tener en cuenta, como un elemento axiológico de la visión cristiana del mundo, la altísima estima del hombre individual, que se entiende coincidentemente al igual que en Aristóteles como un ser plurisignificado. La persona, como ser con posibilidades de apertura a Dios y al demonio (el mal) posee una importancia radical en la cosmovisión semita y cristiana -el hombre es hecho a imagen y semejanza de Dios- Y dice V. Lossky: "La perfección del hombre no radica en lo que lo asemeja al conjunto de las criaturas, sino en lo que lo distingue del cosmos asimilándolo al Creador" (19); Jesús, como nos dice Pannenberg, tiene como centro de su predicación al hombre individual, como lo evidencian muy claramente sus parábolas acerca de la oveja perdida, de la moneda perdida y del hijo pródigo (Lc 15). Siguiendo a Pannenberg encontramos la siguiente afirmación, que resulta muy esclarecedora:

"Esta estima del hombre individual se expresa también y no precisamente en último lugar, en la esperanza judía y cristiana de la resurrección, en la medida en que el contenido de esta es la participación de los individuos que en las generaciones pasadas estuvieron unidos a Dios en el cumplimiento de la historia de la humanidad que se realiza en el reino de Dios. Pero la alta estima en que se tiene a la vida del hombre individual no se sigue en modo alguno el desprecio de la naturaleza extrahumana" (20).

Sin duda alguna, el mensaje de Dios se dirige a la tierra y al hombre, y muestra el interés que tiene Dios en el porvenir del ser humano (Ez 36, 1-15). A la sana

(19) Vladimir Lossky, Teología mística de la iglesia de oriente, Barcelona, Herder, 1982, p. 84.

(20) Pannenberg, ob. cit., p. 97. 
teología - cosa que sí le sucedió a las ciencias sociales- no se le ha perdido la persona humana, fundamento axiológico de la imagen del ser creado y fundamento de la posibilidad del cambio cultural que reclama el ambientalismo como condición indispensable para superar la crisis planetaria: el cambio cultural es un proceso que acontece en individuos no opera sobre conceptos abstractos, tales como organización social o estructura social. El individuo, junto a desarrollos normativos o jurídicos es el que se transforma.

Las relaciones de lo divino con la naturaleza excluyen en algunas oportunidades la referencia a lo humano, dándole con ello un mensaje cósmico, mucho más amplio de lo que podríamos encontrar en una sociedad pastoril y, por tanto, poco igualitaria. En este sentido, es necesario enfatizar que el mandato de dominación del Génesis 1, 26,28 y 2,19 dado a Adán sobre la biota, solo puede ser comprendido entendiendo el trasfondo cultural y el ethos de un pueblo que pocas relaciones simétricas había experimentado por su condición de sociedad de rango. Esas expresiones culturales se van a plasmar en diferentes textos de la Biblia. En el mundo bíblico, Adán domina sobre Eva, los patriarcas sobre sus extensas familias y sirvientes, y los reyes sobre las naciones. El sol domina sobre el día y la luna sobre la noche (Gen 1, 16). Leviatán aparentemente domina sobre el mar (Job 40, 25-32, 41, 1-26) y Behemoth, el mundo de los animales terrestres (Job 40, 15-24), y Dios domina sobre todo (Job 38, 25-27, 39, 9-13; Ecles 11, 5). Sin embargo, sobre la idea de dominación también encontramos un mensaje que nos habla de un cambio profundo en las relaciones ambientales, marcado por el equilibrio entre los seres vivos:

"Habitará el lobo juntamente con el cordero; y el tigre estará echado junto al cabrito; y el becerro, el león y la oveja andarán juntos, y un niño pequeño será su pastor".

El becerro y el oso irán a los mismos pastos; y estarán echados en un mismo sitio sus crías: y el león comerá paja como el buey; y el niño que aún mama estará jugando en el agujero de un áspid; y el recién destetado meterá la mano en la madriguera del basilisco. Ellos no dañarán ni matarán en todo monte santo; porque el conocimiento del Señor llenará la tierra, como las aguas llenan el mar (Is 11, 6-9)".

El mundo no humano participa también de las bendiciones de Dios. Es la maldad de la naturaleza caída del hombre la que impide que las energías trinitarias se expandan planetariamente:

"Y el Señor enviará lluvia a tus sementeras, en cualquier parte de la tierra en que hayas sembrado; las mieses darán abundante y rico trigo; y al mismo tiempo hallarán tus corderos pingües y dilatados pastos en tus heredades.

Y tus bueyes y pollinos que trabajan la tierra, comerán el pienso mezclado con variedad de granos, del modo que aventados de la era, o limpios de paja.

Y de todo monte alto y de todo collado elevado correrán arroyos de fértiles aguas en el día aquel en que habrá gran mortandad, cuando habrían caído las torres. 
Y la luz de la luna será como la luz del sol, y la del sol será siete veces mayor que sería la luz reunida de siete días; en aquel día en que el Señor habrá vendado la herida de su pueblo, y sanado la abierta llaga (Is 30, 23-26)".

Uno de los problemas que se le achacan a la Biblia por parte de algunos ambientalistas es la censura que establece al animismo y a la adoración de la naturaleza. Se considera -erróneamente- que los pueblos politeístas y animistas son sine quo non más ambientalistas que los pueblos monoteístas. Reconociendo que el Antiguo Testamento, en ocasiones, censura la adoración de objetos celestiales, piedras o de las imágenes animales egipcias, y que condena severamente la veneración de imágenes manufacturadas, lo cierto es que la naturaleza y sus paisajes siempre proporcionaron, tanto a judíos como a los pueblos politeístas vecinos, soportes para posibilitar la expresión de la hierofanía y del misterio de Dios:

"El desierto y el yermo se alegrarán, y se regocijará el Arabá y florecerá como el azafrán (Is 35,1); florecerá copiosamente y se regocijará en gran manera y gritará de júbilo. La gloria del Líbano le será dada, la majestad del Carmelo y de Sarón. Ellos verán la gloria del Señor, la majestad de nuestro Dios (Isa $35: 2)$ ".

Se puede afirmar que el concepto administrativo de la naturaleza se convierte en una idea reiterativa en el Antiguo Testamento, tal y como se enuncia en el Libro de la Sabiduría 9: 1-4: "Dios de los padres y señor de la misericordia que con tu palabra hiciste las cosas. Y en tu sabiduría formaste al hombre para que dominase sobre sus criaturas, y para regir al mundo con santidad y justicia, para administrar justicia con rectitud de corazón".

El fin de la historia, desde la escatología judeocristiana, involucra una dimensión cosmológica, escatológica y política concretada en la promesa de "la tierra nueva y los cielos nuevos" (21). "He aquí que vienen los tiempos, dice el Señor, en los cuales el que está aún arando verá ya detrás de sí al que siega; y aquel que pisa las uvas, verá tras de sí al que siembra. Los montes destilarán delicias, y serán cultivados todos los collados" (Am 9, 13). Esto es una paradoja, puesto que lo político, como compromiso con el mundo, es de cierta manera un rompimiento con la visión escatológica, que en una rigurosa visión de la antropología cultural, es la expresión de un rico contenido de carácter mitológico que comparte el cristianismo con el mundo de arriba que ha sido tematizado en los ricos universos culturales de las sociedades tradicionales de todos los tiempos.

Los problemas ambientales visualizados en la Biblia se originan por las contradicciones inherentes a los sistemas culturales y a la presencia del mal, debida a la naturaleza caída del hombre. El hombre, en su devenir histórico (Gen 3, 17-18), contamina la tierra y hace que ella sea objeto de la maldición divina. Las alianzas que Dios realiza con la humanidad después del diluvio abarcan también el universo material:

(21) E. Beaucamp, La Biblia y el sentido religioso del universo, Bilbao, Mensajero, 1966, pp. 188205 
"Y el Señor se complació en aquel olor de suavidad y dijo: nunca más maldeciré la tierra por las culpas de los hombres, atento a que los sentidos y pensamientos del corazón humano están inclinados al mal desde su mocedad; no castigaré, pues, más a todos los vivientes como he hecho (Gen 8, 21-22)”.

El Compendio de la doctrina social de la Iglesia, establece claramente como fundamentación ética que en "el origen de estos problemas se puede percibir la pretensión de ejercer un dominio absoluto sobre las cosas por parte del hombre, un hombre indiferente a las consideraciones de orden moral que deben caracterizar toda actividad humana" (22).

\section{Las promesas y desafíos en el Nuevo Testamento}

El Nuevo Testamento sella definitivamente el desenlace de las promesas de Dios, introduciendo las enseñanzas de Jesús; su mensaje responde de manera concreta y hace visible los principales interrogantes axiológicos sobre el sentido de la vida. La cruz cristiana se implanta como uno de los mensajes más revolucionarios en la historia del hombre.

El lenguaje de Jesús está lleno de alusiones a la naturaleza; las imágenes del medio natural son utilizadas para recrear y simbolizar los diversos aspectos y condiciones del reino de Dios. El método pedagógico por excelencia de Jesús, la parábola, recurre reiterativamente a hechos relacionados con los ciclos agrícolas, donde palabras como: siembra, siega, cizaña, grano de mostaza, higuera, viña, sol, lluvia, lirios del campo, agua, árbol y montaña, entre otros, revelan cómo la vida de Jesús y el modelo que nos propone es una invitación, un reto y un desafío para que el hombre entre en armonía consigo mismo y con el resto del cosmos. Indudablemente, la vida ejemplificante de Jesús es el eje axiológico para la acción ambiental. El Salvador en su propia persona nos expone un modelo de vida basado en la paciencia, amor a la humanidad, bondad, fortaleza, misericordia, justicia y amor a los seres creados, amor al enemigo, compromiso profético y denuncia de la injusticia.

La plenitud final del universo, simbolizada en el "nuevo cielo y la nueva tierra" del trito Isaías, llega a su culmen en Jesús, quien aparece vinculado directamente con esa tradición profética (2 P 3, 13 y Ap 21, 1.); En Mt 19, 28 se anuncia una regeneración del cosmos, que se puede entender en sentido universal si se tiene en cuenta a Hch 3,21. El desafío se va clarificando por la presencia y vivencia cristiana de los apóstoles que, iluminados por el Espíritu Santo, entienden cómo el señorío del hombre es un reto para toda la creación, que se formula de manera muy clara en el pasaje de Rom 8, 19-23:

"Pues la ansiosa espera de la creación desea vivamente la revelación de los hijos de Dios. La Creación, en efecto, fue sometida a la vanidad, no espontáneamente, sino por aquel que la sometió en la esperanza de ser liberada de la servidumbre de la corrupción, para participar en la gloriosa libertad de los

(22) Pontificio Consejo Justicia y Paz, Compendio de la doctrina social de la Iglesia, Bogotá, Conferencia Episcopal de Colombia, 2007, p. 283. 
hijos de Dios. Pues sabemos que la creación entera gime hasta el presente y sufre dolores de parto. Y no solo ella; también nosotros, que poseemos las primicias del espíritu, nosotros mismos gemimos en nuestro interior, anhelando el rescate de nuestro cuerpo".

Como comenta Lyonnet (23), el anterior texto contiene tres afirmaciones fundamentales:

a) la suerte del universo está ligada a la del hombre; este arrastró a aquella en su destino de corrupción (vv. 20-21) y los hará partícipes de su liberación (v. 21); por eso la creación "desea vivamente la revelación de los hijos de Dios" (v. 19). b) Más concretamente la redención del universo pende del rescate de nuestro cuerpo (v. 23), es un corolario de la resurrección; a esta alude ya el v. 18 cuando habla de la "gloria que se ha de manifestar en nosotros", es decir, de la transfiguración de nuestra corporeidad a imagen de la de Cristo resucitado, será entonces, en efecto, cuando se revele (v. 19) nuestra condición filial, porque nuestros cuerpos reproducirán la gloria del Hijo (Ef. v. 29 y 2 Co 3, 18). c) Con todo, la redención del universo no consiste simplemente en la resurrección del universo, atañe al universo mismo que "será liberado" de lo que hay en él actualmente de vanidad, esclavitud y corrupción (v. 21).

Continúa Lyonnet afirmando cómo el realismo con que se predica de la creación entera en función de la transformación futura, es acentuado enfáticamente por Pablo con la vigorosa imagen del v. 22, que nos presenta un universo gimiendo en dolores de parto; la nueva creación se está gestando ahora y será alumbrada por el mundo presente. A esta aserción, el apóstol le antepone un sabemos en efecto (oidamen gar) que, en el vocabulario paulino, introduce generalmente una doctrina de fe, y no una mera opinión del autor.

La armonía y la paz tan anhelada por los ambientalistas y todo hombre de bien, tiene como modelo a Jesús y su Iglesia. Jesús, hombre de oración y plegaria quiso hacerse a una Iglesia. El mundo tiene que transfigurarse con base en las verdades del evangelio. La tarea -como indicaba J. Maritain- es incorporar las verdades del evangelio en la realidad sociotemporal del mundo en que vivimos. Lo que afirma Rom 8, 19-23, tiene implicaciones cósmicas, ya que la tierra, el mundo vegetal, y el mundo animal participan y esperan (en) la deificación del hombre.

\section{Testimonios de la tradición cristiana}

Los mejores testimonios para una escuela humanista ambiental los encontraremos en las vidas y acciones de los hombres y mujeres de Iglesia que han acogido el camino de la unión con Dios con todo su ser y como forma para transformar su ser. Toda la voluntad, la inteligencia y la afectividad se colocan en el centro del camino y del abismo divino. La criatura es susceptible de transformarse. Podemos pasar de un estado a otro. El hombre puede abandonar sus pulsiones neuróticas, sicóticos,

(23) Tomado de: Instituto Internacional de Teología a Distancia José Ortega y Gasset, 1979, Escatología cristiana, Madrid, pp. 49-50 citando a Lyonnet, Stanislas S.J., Presencia de Cristo y de su espíritu en el hombre. Concillium: Revista Internacional de Teología Año 5 Tomo 3, No 50 (jul.dic. 1969), pp. 566-578. 
egoístas y esquizoides. El proceso dinámico de nuestros santos ha hecho historia. Dichas historias aparecen siempre como algo absolutamente nuevo que genera en el plano social cosas buenas y bellas, alegría, sabiduría, himnos maravillosamente compuestos y ordenaciones musicales dirigidas a Dios.

Los diferentes miembros de la Iglesia: mártires, padres, monjes, santos, hombres ordinarios, y laicos a lo largo de su vida, han encontrado una fuente inagotable de tesoros y enseñanzas en la naturaleza, que debido a las mismas condiciones culturales, nunca se vio amenazada de manera planetaria. La vida monástica, por ejemplo, más que cualquier otro movimiento cristiano, ha estado generalmente asociada a la vida en la campiña, en los bosques y en los desiertos. Los primeros ermitaños, tales como san Antonio, huyeron al desierto de Egipto y Palestina. Al principio desarrollaron su vida en la soledad personal, residiendo aisladamente en cuevas, edificios abandonados e incluso tumbas. Posteriormente, a partir del Imperio Romano y hasta el presente, se organizaron en comunidades. Difundiéndose más allá de Egipto y de Palestina, se fundaron decenas de órdenes religiosas. Los franciscanos y benedictinos son tan solo algunas de las órdenes más conocidas. En particular, los benedictinos se pueden considerar como los maestros del amor por la naturaleza en Europa.

Una de las más tempranas e influyentes biografías del monaquismo es La vida de san Antonio, escrita por Atanasio, quien también fue un monje. En algunos apartes de la biografía se indica claramente la actitud festiva y amorosa (agape) que tenía el monje con respecto al medio natural. Las montañas aparecen teniendo "agua, claramente cristalina, dulce y muy fría". Para poder sobrevivir se dedicaron a la agricultura de pequeños huertos, donde cosechaban vegetales. La vida en el desierto - un ecosistema árido- resultaba hermosa y útil en la vía de la unión con Dios. Los monjes eran sensibles a los encantos del medio natural y, cuando refieren sus experiencias, el mundo creado es descrito claramente. En suma, el monje cristiano y su modelo místico ve en el ecosistema del desierto un medio o canal para ejercitarse espiritualmente, antes que un espacio para recrear una visión o profecía (24). En ese sentido, la espiritualidad cristiana es eminentemente sobria. La vida solitaria y campestre del monje no se vinculaba a lo material, a valores estéticos o chamánicos; lo principal eran los valores personales y espirituales. La soledad y la vida campestre estaban necesariamente ligadas con la purificación del corazón y de todo el ser. Era el lugar privilegiado para activar la oración del corazón y para encontrarse con aquel que está más allá de cualquier palabra, imagen o concepto.

Posteriormente, el desarrollo del dogma cristiano irá dibujando en el paisaje afirmaciones valiosas que permiten entender el sentido cósmico en la relación hombre-naturaleza. En el siglo IV, san Agustín, en su sermón 261, decía: “Toda la tierra es como una reliquia tuya, una presencia de tus obras..." Orígenes veía la influencia divina, no solo en el hombre, sino en la naturaleza: "La mano del Señor no ha descuidado los cuerpos de los animales más pequeños... no ha descuidado tampoco las plantas de la tierra que tienen cada una un detalle que lleva en sí el arte divino..." (25).

(24) S. Power, "The original Desert Solitaire: Early Christian Monasticism and Wilderness", Environmental Ethics, vol. 10, núm. 1, University of Georgia, 1988, p. 48.

(25) Tomado de: Cárdenas, Felipe, Antropología y ambiente, Bogotá, Javergraf, 2002, p.102. 
ISAAC el Sirio, en el siglo XI, en sus Tratados ascéticos (Tratado 81) plantea una relación profundamente mística con la naturaleza:

“¿Qué es brevemente la pureza? Es un corazón que se compadece de toda naturaleza creada... ¿Qué es un corazón compasivo? Es un corazón que arde por toda la Creación, por los hombres, por los pájaros, por las bestias, por los demonios, por todo tipo de criatura. Cuando piensa en ellos, los ve, sus ojos vierten lágrimas. Tan fuerte y tan violenta es su compasión... que su corazón se rompe cuando ve el mal y el sufrimiento de las criaturas más humildes. Por eso, reza con las lágrimas a cualquier hora... por los enemigos de la verdad y por todos aquellos que le dañan, para que sean guardados y perdonados. Incluso reza por las serpientes con la inmensa compasión sin medida, que se eleva en su corazón a imagen de Dios".

En términos prácticos, el monaquismo cristiano ha vivido interesantes momentos de pobreza evangélica que pueden visualizarse como ricos modelos antimaterialistas y, por tanto, entenderse como ideas-fuerza para el pensamiento ambiental. La temprana regla monástica de san Pacomio nos ilustra sobre el sentido de vida de las primeras comunidades monásticas que existieron en Egipto y Etiopía:

"En sus celdas no tienen más que una estera y los objetos siguientes: dos túnicas (especie de vestido egipcio sin mangas) y una tercera ya usada que usan para dormir o trabajar, un manto de lino, una piel de cabra a la que llaman melota, dos cogullas, un pequeño cinto de lino, calzado y un bastón como compañero de viaje.

Los enfermos son restablecidos gracias a cuidados admirables y comidas copiosas. Los que se hallan en buena salud se benefician de una abstinencia más severa; ayunan dos veces por semana, los miércoles y viernes, salvo durante el tiempo que va de Pascua a Pentecostés. Los demás días, los que lo desean comen después de la hora sexta y a la tarde se vuelve a poner la mesa a causa de los que trabajan, de los ancianos, de los niños y del intensísimo calor. Algunos comen poco la segunda vez, otros se contentan con una sola comida: el almuerzo o la cena. Algunos toman solo un poco de pan y salen del refectorio. Todos comen al mismo tiempo. Cuando alguno no quiere ir a la mesa, recibe en su celda solamente pan, agua y sal, todos los días o día por medio según lo desee”.

El monacato occidental tiene como su patriarca a san Benito de Nursia, patrón de Europa. Su lema: "Ora et labora", es una síntesis que expresa la calidad de la salud espiritual del cristianismo y refleja la deuda que tiene Europa con el movimiento benedictino, que logró mantener y perfeccionar toda una tradición de trabajo con la tierra, precursora de todas las modernas agriculturas ecológicas. Como muchos cristianos, Benito se desilusionó con la vida del siglo y sus vanidades, se retiró a Enfide (la actual Affile), para dedicarse al estudio y practicar una vida de rigurosa disciplina ascética. No satisfecho con esa relativa soledad, a los pocos años se fue al monte Subiaco bajo la guía de un ermitaño y vivió en una cueva. Tres años después se fue con los monjes de Vicovaro. No duró allí mucho tiempo ya que lo eligieron prior, pero después trataron de envenenarlo por la disciplina que les exigía. Con un 
grupo de jóvenes, entre ellos Plácido y Mauro, fundó su primer monasterio en la montaña de Cassino en 529. Fundó numerosos monasterios, centros de formación y cultura capaces de propagar la fe en tiempos de crisis. Se levantaba a las dos de la madrugada a rezar los salmos. Pasaba horas rezando y meditando. Hacía también horas de trabajo manual, imitando a Jesucristo. Veía el trabajo como algo honroso. $\mathrm{Su}$ dieta era vegetariana y ayunaba diariamente, sin comer nada hasta la tarde. Recibía a muchos para dirección espiritual. Algunas veces acudía a los pueblos con sus monjes a predicar. Era famoso por su trato amable con todos. Se dice que fue un poderoso exorcista que tuvo mucho amor por la Cruz. El don para someter a los espíritus malignos lo ejerció utilizando la famosa Cruz de san Benito (26). San Benito regulaba diversos aspectos de la vida de sus monjes, que basaban su sustento en una libra de pan y una hemina de vino. Decía:

"nosotros no se lo negaremos a las reclusas más delicadas y de menor resistencia. Sin embargo, es sumamente provechoso, para las más jóvenes, abstenerse de aquello que pudiera embriagar.

"Se servirá un plato de verduras o legumbres o al menos de pasta de harinas, con un poco de aceite, mantequilla o leche para suavizar la aspereza de la condimentación, y con ello tendrá suficiente, aunque después vaya a cenar. A la cena tome un poco de leche, pescado o algo semejante que tenga más a mano y deberá conformarse con una porción, a la que añadirá fruta o ensalada si la tiene" (27).

Una variante de la vida monástica fue la reclusión, que adoptó dos formas diversas: la práctica de la vida solitaria, garantizada plenamente en un lugar deshabitado, o bien la vida solitaria en estricta clausura perpetua. Según Ignacio Aranguren, O.C.S.O., en referencia a un tratado de san Elredo de Rieval, la reclusión fue muy frecuente como género de vida religiosa, desde los tiempos de la paz constantiniana hasta la Edad Media.

En una pequeña obra titulada Vida reclusa, escrita entre 1160-1162 por san Elredo de Rieval para su hermana, una reclusa, encontramos vínculos con el tema de la alimentación y el vestido que nos conectan con la frugalidad del pensamiento y la conducta aparentemente "antisocial", pero ecológica, de estos "seres primitivos", de quienes tendríamos que aprender mucho en estos tiempos de consumo desmedido: "Me parece una redundancia, querida hermana, tratar de proponerte una norma sobre la cantidad y calidad de tus alimentos, cuando ya desde la misma infancia hasta tu ancianidad, que ahora debilita ya tus miembros, han alimentado tu cuerpo con extrema frugalidad..."

El contexto espiritual en el que les tocó moverse a muchos de los autores cristianos más importantes de la Iglesia, no fue, como puede pensarse, el del dominio absoluto de las doctrinas cristianas, sino todo lo contrario; esos tiempos, estaban llenos de movimientos seudomísticos y religiosos: albigenses, pobres de Lyon, franciscanos espirituales, lollardos, cellistas, hermanos del libre espíritu... Como nos

(26) Butler, Vidas de los Santos,

(27) Ibíd., p. 106. 
dice Teodoro H. Martín, "grupos diferentes que solían coincidir en estos puntos: visión panteísta del mundo, ociosidad, quietismo nirvanesco, naturalismo sensual, negación de los Sacramentos, protesta antijerárquica" (28).

Como personaje emblemático de la Edad Media, la referencia obligada es Francisco de Asís. Un fragmento de su obra más conocida, El Cántico a las criaturas (1225) nos recuerda el sentido que tenía la naturalaza creada y el simbolismo:

"Loado seas, mi Señor, con todas tus criaturas,

Especialmente el señor hermano Sol,

El cual es día y por el cual nos alumbras.

Y él es bello y radiante con gran esplendor, se parece a ti

Loado seas, mi Señor, por la hermana Luna y las Estrellas;

En el cielo las has formado luminosas, preciosas, y bellas".

La naturaleza, para Francisco era una vía para conocer y acercarse a Dios. Los ecosistemas naturales y silvestres eran, para él, espacios que comunicaban las cualidades trascendentes, místicas e innombrables de Dios. Todos los animales expresaban su cercanía a Francisco y a todos los tenía por hermanos y hermanas. Su experiencia mística transcurre y evoluciona en el mundo de la campiña, la montaña de La Verna y los bosques de la Toscana italiana. Se ha considerado tan importante el aporte de la espiritualidad de Francisco, que en el año de 1979, el Papa Juan Pablo II lo declaró como el santo patrono de la ecología. Francisco enseñó a mirar a través de la naturaleza la revelación íntima de la acción de Dios. El franciscanismo contradice cualquier juicio que afirme que el cristianismo está desunido de la naturaleza. El cardenal Joseph Ratzinger, hoy Benedicto XVI, también ha realizado referencias a él, y nos recuerda el papel del pesebre cristiano, novedad que fue instalada por Francisco en la tradición de la vida de la Iglesia (29).

Uno de los escritores místicos más importantes en la historia de la Iglesia, hoy menos popular que san Francisco, es el beato Juan Ruysbroeck (1293-1381), llamado el místico de Flandes. Se encuentra en Ruysbroeck uno de los más hermosos e interesantes trabajos que, enmarcado dentro de la tradición de la unión con Dios proveniente de la tradición teológica Areopagítica (siglo IV), nos revela valiosos testimonios de lo que es el mundo natural para el místico cristiano.

El camino o la vía de unión con Dios que tienen que recorrer todos los hombres aparece en Ruysbroeck constituido a partir de la utilización de metáforas muy ricas en cuanto a la observación del entorno natural y el funcionamiento de los ecosistemas. En el camino de encuentro con Dios, propuesto por el místico de Flandes, el hombre debe partir de "tener presente a Dios en todas las cosas" (30).

El beato Juan, en su doctrina espiritual, propone claramente como guía hacia la deificación del hombre, metáforas riquísimas que nos dan a entender, en un primer lugar, su genio observador de los fenómenos del cosmos, y, en segundo lugar, la estructura interpretativa subyacente a su mensaje en el contexto de la relación hom-

(28) Teodoro H. Martín, 1989, p. 16.

(29) El rostro de Dios, Salamanca, Ediciones Sigueme, 1983, pp. 19-25.

(30) J. Ruybroeck, Bodas del alma y la piedra brillante, Salamanca, Sígueme, 1989, cap. XXV. 
bre-Dios-naturaleza. En su libro Bodas del alma, el capítulo XVII está orientado totalmente a referirnos cómo se desenvuelve un proceso de maduración espiritual, utilizando ideas y nociones referidas a los procesos del mundo de la naturaleza:

"Cuando llega el verano y se levanta el sol, su calor desprende la humedad de la tierra. Luego las raíces y el tronco mismo de los árboles la absorben hasta las ramas, de donde brotan hojas, flores, y frutos. De la misma manera, cuando Cristo, Sol eterno, se levanta y sube hasta nuestro corazón, haciendo nacer allí el verano con el aderezo de virtudes, da su luz y calor a nuestros deseos" (31).

La vía de la unión atraviesa, en la concepción de Ruysbroeck, por periodos de escarcha y niebla (cap. XXI) y se asemeja a la vida de la abeja (cap. XXII) que: "vive unida al grupo de sus semejantes. Sale cuando el tiempo está calmo, sereno de sol. No en la tempestad. Se poda sobre flores en que halla cualquier néctar suave. No descansa en ninguna flor ni sobre cosa alguna que la deleita por su belleza o suavidad. En cambio, liba la miel y la cera, es decir, la dulzura y materia de que se alimenta la claridad de la llama. Luego vuelve a reunirse con todo el enjambre para hacerse fecunda y sacar provecho de su botín. El corazón se dilata donde resplandece Cristo, sol de eternidad. Crece bajo sus rayos, florece y se expande con todas las potencias interiores en alegría y dulzuras" (32).

La contemplación cristiana en Ruysbroeck está muy unida al simbolismo de la naturaleza. Sus observaciones van más allá de un ingenuo panteísmo; en general, el simbolismo de la naturaleza de Juan se despliega y sigue en toda su profundidad las tres edades de la vida interior: purgativa, iluminativa y unitiva. En cada una de estas tres etapas, el mundo natural será el soporte fundamental para comunicar la riqueza de la vida espiritual del cristiano; esa riqueza se entiende como hambre insaciable (cap. LV), como una llamarada (cap. LIV), o como un proceso de preparación interior para las constantes venidas de Cristo a la vida de todos los seres que la quieren experimentar permanentemente; en ese sentido, se entiende a Jesús como una fuente viva con tres arroyos (cap. XXXVI). Los arroyos representan las maneras particulares con que Dios influye y actúa sobre las potencias espirituales. El primer arroyo se refiere a la memoria o permanente gracia de Dios que corre y fluye hacia el hombre (cap. XXXVII). El segundo arroyo se refiere al entendimiento que Dios les confiere a los hombres (cap. XXXVIII). El tercer arroyo es la voluntad y se expresa como:

"El gozo, la gracia abundante y la fidelidad divina [que] hacen que mane y corra... Arroyo que inflama la voluntad al modo del fuego, porque devora y consume todas las cosas reduciéndolas a la unidad. Luego inunda e invade las potencias del alma confiriéndoles la abundancia de sus dones y nobleza singular" (33).

(31) Ibíd., p. 80

(32) Ibíd., p. 83.

(33) Ibíd., cap. XL, p. 104. 
Debemos recordar cómo en la Edad Media, al igual que en la era patrística, el simbolismo expresaba una profunda relación entre lo creado y lo increado. Los números expresaron la armonía del mundo natural y sobrenatural. Como otros pensadores cristianos, Ruysbroeck recogió muchas imágenes de la mentalidad popular y las transformó en "vehículos" de gracia en el sentido más sociológico del término.

Vemos cómo los padres, tanto de la Iglesia de Occidente como de Oriente, le han otorgado a la naturaleza una importante función como soporte constitutivo del cosmos y de la vida del hombre, a lo largo del desarrollo evolutivo de los dogmas. Como hemos visto, en un gran número de autores cristianos, surgidos en contextos temporales y culturales muy diversos, nos encontramos con interesantes enfoques referidos a la relación ser humano-naturaleza.

Ya en épocas más recientes, los papas han manifestado un hondo interés por los problemas ambientales; el Papa Pablo VI, en su Encíclica Populorum Progressio, comenta en relación con el problema del colonialismo y neocolonialismo que: "Ciertamente hay que reconocer que las potencias coloniales con frecuencia han perseguido su propio interés, su poder o su gloria, y que al retirarse a veces han dejado una situación económica vulnerable ligada, por ejemplo, al monocultivo cuyo rendimiento económico está sometido a bruscas y amplias variaciones".

Adicionalmente, en su Octogésima Adveniens, precisa aún más proféticamente lo relacionado con las aniquilantes actitudes de los seres humanos: "Por causa de una explotación irracional y desaprensiva de la naturaleza, el hombre puede destruirla y pasar a ser víctima de su degradación".

El tema ambiental hizo parte de una de las principales preocupaciones del magisterio de Juan Pablo II. En diversos momentos señaló como problemas del mundo moderno y como obstáculos para la paz los conflictos armados, las injusticias sociales y la falta de respeto y veneración por parte del hombre hacia la naturaleza, expresada en el uso irracional de los recursos naturales. Estos fenómenos -según él- son elementos explicativos del acelerado deterioro en la calidad de vida de los habitantes del planeta:

"La época moderna ha experimentado la creciente capacidad de intervención transformadora del hombre. El aspecto de conquista y de explotación de los recursos ha llegado a predominar y a extenderse, y amenaza hoy la misma capacidad de acogida del medio ambiente: el ambiente como recurso pone en peligro el ambiente como casa. A causa de los poderosos medios de transformación que brinda la civilización tecnológica a veces parece que el equilibrio hombre-ambiente ha alcanzado un punto crítico" (34).

En 1979, la Iglesia Católica latinoamericana, reunida en Puebla, México, declaraba lo siguiente: "Si no se cambian las tendencias actuales, se seguirán deteriorando las relaciones del hombre con la naturaleza, por la explotación irracional de

(34) Juan Pablo II, Discurso a los participantes en un Congreso Internacional sobre "Ambiente y salud" (24 de marzo de 1997), 2: L'Osservatore Romano, edición española, 11 de abril de 1997, p. 7. 
sus recursos naturales y la contaminación ambiental, con graves daños al hombre y al equilibrio ecológico".

Manifestaciones de este tipo se dieron a todo lo largo de la década de los ochenta; las conferencias episcopales de los diferentes países han demostrado una honda preocupación en materia de la relación hombre-naturaleza. Se destaca la urgente necesidad de impulsar programas que promuevan la conservación y la protección del ambiente, fomentando en lo posible una "espiritualidad ecológica".

\section{El papel de la parroquia}

La parroquia, del griego paroikos: habitar cerca; para otros, lugar del destierro, es una de las instituciones más incomprendidas y despreciadas de los tiempos modernos. A partir de mi experiencia en el campo de estudios realizados en los paisajes culturales andinos de Colombia, y conociendo el rol de la parroquia, Iglesia particular, en prácticamente toda la geografía de América Latina, estoy convencido del papel axial que puede cumplir, tanto en sus zonas de influencia urbanas como rurales, en la implantación de una pastoral de cuño ambiental (35).

El lugar privilegiado para la oración comunitaria es la parroquia. Ese es el lugar de lo visible, pero la parroquia moviliza acciones y dimensiones de realidad que no son fácilmente cuantificables ni observables. La fuerza del mensaje de Dios frena la mano destructora del hombre. Hay fenómenos invisibles para las ciencias sociales y, por tanto, para una sociología de la parroquia. ¿Cuántas vidas, itinerarios

(35) Entre los años de 1995-1996 pude comprobar personalmente la importancia de la parroquia y del papel de la vida diocesana en la implementación de una propuesta de desarrollo rural, ligada a la reintroducción del cultivo de la quinua en el municipio de Chita (Boyacá), y a la implementación de propuestas de desarrollo regional y desarrollo sostenible (1992-2000). Gracias al apoyo de la comunidad de fieles y del cura párroco padre Luis Teodoro Bustacara, y contando con el apoyo del obispo, monseñor Hernán Giraldo Jaramillo, se constituyó de manera estable un trabajo que posibilitó la reintroducción del cultivo de la quinua como elemento esencial de una propuesta de mejoramiento nutricional. El "paisaje cultural" boyacense, como muchos de nuestros paisajes americanos, no se puede entender sin la presencia de la parroquia, sus presidios, legionarios y comunidades eclesiales que la conforman. Con sus fieles reunidos en momentos pre o poseucarísticos, se desarrolló la estrategia de comunicación cristiana para la reintroducción de esta rica especie nutricional, que se había perdido hacía por lo menos un siglo debido a los avances modernizadores de la economía nacional, la cual desplazó recursos campesinos e indígenas por considerarlos atrasados y de poco valor.

Contando con la ayuda de fieles, incluso en la celebración dominical de la Eucaristía, en su homilía, la quinua como recurso del Altísimo fue uno de los temas abordados. La parroquia, como lugar de encuentro del pueblo cristiano, fue el espacio para celebrar e introducir temas como el que venimos desarrollando y que permitió reconocer el valor de esta primitiva institución, incluso rechazada en ciertos círculos ilustrados de la Iglesia. Posteriormente, varios sacerdotes empezaron a desarrollar toda una propuesta de pastoral ambiental. Hoy la propuesta mantiene su vigencia y la pastoral ambiental ha permitido que cerros, quebradas, tierras comunales hayan sido protegidas por la acción pastoral que párrocos y pastores han venido desarrollando desde hace ya más de quince años. El calendario litúrgico, las fiestas patronales y celebraciones como el domingo de Ramos y el Corpus Christi, que antaño fueron fiestas que se prestaron para la destrucción y la caza de animales, son hoy festividades que acercan y promueven un comportamiento marcadamente ambiental. Hay evidencias satelitales que demuestran con claridad cómo en los últimos años las talas y quemas de páramos se han reducido sustancialmente con respecto a los niveles de 1992. 
personales, adelantamientos espirituales y personales no se han logrado gracias a la acción dinámica y eucarística que moviliza una parroquia y para la cual ni siquiera su párroco es consciente? Como decía san Juan Crisóstomo (Incomprehens 3, 6):

"No puedes orar en casa como en la iglesia, donde son muchos los reunidos, donde el grito de todos se eleva a Dios como desde un solo corazón. Hay en ella algo más: la unión de los espíritus, la armonía de las almas, el vínculo de la caridad, las oraciones de los sacerdotes".

La parroquia como expresión territorial, con todas sus crisis, es una institución que busca la paz y armonía, bajo la animación de fieles y sacerdotes, está llamada a conservar y transformar silenciosamente el paisaje del continente y promocionar la fuerza del evangelio. Ahora, la participación y animación del laico es indispensable. El cura está ya muy cargado con misas, funerales, bautismos, bodas y demás actividades. La ampliación de la acción ambiental cuenta con toda una geografía de lo sagrado, concretada en capillas, grutas, santuarios, que debe potenciar en toda su plenitud la transformación armoniosa del territorio por acción de las promesas del Evangelio y del Espíritu Santo. La parroquia podría, bajo el apoyo de laicos comprometidos y conocedores de la problemática ambiental y sociocultural, complementar toda una práctica ligada a la promoción de la familia, el desarrollo humano y la valoración de la persona. La parroquia es un factor indudable de identidad cultural en muchos de nuestros pueblos. La parroquia es un referente obligado si se aspira al "despertar de las Iglesias en las almas" (Guardini (36)); es referente para el reconocimiento de los derechos humanos, para el surgimiento de pequeñas comunidades y movimientos apostólicos que responden a carismas personales surgidos "desde abajo"; la parroquia está abierta para que descubramos los tesoros de la Iglesia y para que conectemos la teoría con la práctica. La noción desde abajo se refiere a la construcción de una sociedad que en una de sus estructuras de acogida pueda impulsar toda una serie de valores humanos, donde cada miembro se sienta responsable por el conjunto de dichos valores, que deben despertarse en la parroquia.

La parroquia tendrá que estar atenta a los signos de los tiempos, convocando grupos de estudio que analicen bajo ópticas teológicas y con la ayuda de otras visiones (filosofía, antropología, sociología), los procesos "terrenales" que configuran los espacios físicos, los valores de sus ciudadanos, las relaciones sociales, el papel de los medios, las transformaciones culturales, los nuevos patrones de socialización, las tradiciones, costumbres, hábitos, actitudes y sentimientos propios de la cultura y de la época que le tocó vivir. La parroquia tiene que buscar que el mundo de abajo se oriente por el mundo de arriba: "Venga a nosotros tu Reino", no "venga el reino de los hombres al cielo".

Por encima de cualquier innovación sociológica, la parroquia nos ha sido dada para la oración y la celebración de los oficios y la liturgia. La meta de la parroquia es la santificación de sus fieles. Su pastoral debe llevar a que todos participen activamente en los oficios divinos, especialmente en la eucaristía, y debe irradiar la necesidad y

(36) Conversación personal con José Benjamín Rodríguez Iturbe. 
el deseo de que la oración interior esté siempre y en todas partes con nosotros. El que ama al Señor se acuerda siempre de Él, y el recuerdo de Dios hace brotar la oración. La principal fuerza del cristiano es la oración. Ella tiene resonancia cósmica.

El fin de la parroquia, como el de la vida cristiana, no está ligado a la implantación de un sistema ideológico fabricado por los hombres. El fin de la vida cristiana, y que cuenta con estructuras de soporte y acogida como la parroquia, y otras formas no territoriales (p.e Prelaturas Personales como el Opus Dei), es la vida en Cristo, la adquisición de la gracia del Espíritu Santo y la santificación personal y comunitaria de la feligresía.

De los tesoros del patrimonio de nuestra Iglesia: la parroquia de la Iglesia Ortodoxa etíope (37)

Gracias a mi amigo etíope Ezana Habte, me llegó una información valiosa que transcribo, para ilustrar aún más el valor de la parroquia en ámbitos geográficos que han sufrido fuertes presiones antrópicas que han transformado radicalmente las condiciones ecosistémicas de los bosques. Alemayehu Wassie, ingeniero forestal y agrónomo reporta en un trabajo titulado: Ethiopian orthodox tewahido church forests: The Blue Prints of the lost forest resources in the Northern Highlands of Ethiopía, el importante papel de la Iglesia etíope en la conservación de bosques naturales (38):

Como ha sucedido en muchos países del mundo, el incremento en las tasas de deforestación ha eliminado prácticamente los bosques en Etiopía, lo que ha traído una significativa reducción en la biodiversidad, con el agravante de que algunas especies están a punto de extinguirse. El problema es el resultado de la larga presencia humana en el territorio, acompañada por una agricultura intensiva y ganadería extensiva. Para el autor, el crecimiento en las poblaciones animales y humanas ha deteriorado el medio natural.

Según cuenta el autor, ha sido muy difícil recuperar los paisajes degradados y las áreas devastadas por la acción humana a través de los siglos. Mantener la diversidad forestal ha sido una tarea muy retadora, la mayoría de los enfoques forestales y ecológicos han fracasado. Las únicas áreas donde se pueden observar remanentes y parches boscosos en el norte de Etiopía son los alrededores de las Iglesias. Los remanentes boscosos han sobrevivido como resultado de los sistemas de conservación tradicional y medidas impulsadas por el patronato protector de la Iglesia Tewahido Etíope Ortodoxa.

La Iglesia Tewahido Etíope Ortodoxa (EOTC) es una iglesia autóctona, miembro integral de la Iglesia Cristiana de África. Es una de las iglesias más antiguas del mundo. La palabra "Tewahido" es el término etíope que significa "hecho uno", la

(37) Para mayor amplitud sobre la Iglesia etíope consúltese el trabajo de Dom Colin Battel, The Ethiopian OrthodoxChurch and its monastic tradition. Disponible en http:// www.benedictines.org.uk/theology/2005/battell.pdf

(38) Alemayehu Wassie, Ethiopian Orthodox Tewahido Church Forests: The Blue Prints of the lost forest resources in the Northern Highlands of Ethiopia, 2004. Disponible en http:// www.geocities.com/akababi/eotc_forest_1.htm 
mejor expresión sobre la fe en la Iglesia. Enfatiza la inseparable unidad entre Dios y la humanidad en la persona de Cristo. La Iglesia etíope se considera que pertenece a la Una, Santa, Universal y apostólica Iglesia fundada por Jesucristo.

El cristianismo llegó a Etiopía desde los tiempos de los apóstoles. Ha mantenido la doctrina de Cristo, como se narra en la Biblia (Hechos 8:26-39). El EOTC es numéricamente la más grande de las cinco iglesias del este no caldeanas -la copta, la etíope, la Siria, la india y la Armenia-. Históricamente fueron llamados "las iglesias ortodoxas orientales" para distinguirlas de las iglesias ortodoxas bizantinas. Tiene más de 40 millones de fieles, 400.000 religiosos y 35.000 iglesias en Etiopía. Por otra parte, tiene varios fieles y arzobispos en otros países. El EOTC cree que la Iglesia es una comunidad fundada por Dios, crucificado, levantado y glorificado en Cristo, el Hijo encarnado de Dios, dirigido y limitado por Dios.

Las iglesias se construyen en puntos agradables y se rodean generalmente con las paredes de piedra y de remiendos masivos de los árboles, que agregan solemnidad y le imprimen quietud al edificio. Los lugareños usan los árboles circundantes para darles nombre a sus iglesias, como Debr o Geddam, el cual es visto por los seguidores como el lugar más santo y religioso; asimismo, es un centro social respetado y de gran alcance institucional. Los ambientes exteriores son sitios hermosos rodeados por un paisaje boscoso que atestigua lo que fueron los ecosistemas hace unos años. Una iglesia es también un edificio para la adoración; sus alrededores, como su interior, son sagrados, por tanto protegidos de la acción destructora de los hombres. Los ecosistemas "sagrados" que se constituyen alrededor de ellas, son visibles a grandes distancias y tienen un aspecto majestuoso; generalmente, la iglesia está construida sobre una pequeña colina cercana a una aldea. La Iglesia Ortodoxa Etíope de Tewahido tiene una larga historia ligada al repoblamiento forestal, la protección y preservación de árboles. En el norte de Etiopía, la escasez de árboles es muy evidente en el paisaje, la excepción a la regla está dada por los alrededores de una iglesia. Si un viajero puede ver árboles altos y viejos, con toda seguridad se encuentra una iglesia en el lugar.

La función principal de las iglesias es litúrgica y sacramental; sin embargo, también proporcionan hábitat y refugios únicos para microorganismos, flora y fauna; también la gente cuenta con un lugar de descanso y meditación. Muchos árboles y arbustos endémicos o autóctonos, que fueron destruidos totalmente durante el siglo pasado, siguen manteniéndose en pie en los alrededores de las iglesias rurales. Consecuentemente, estos bosques son santuarios para diversos organismos: microorganismos, animales grandes, que casi han desaparecido en otras partes. Son los alrededores de un monasterio o una iglesia los que mantienen todavía una porción de la biota del país. Ningún sistema agroforestal o práctica ecológica ha frenado la deforestación en el país, que se calcula en unas 200.000 hectáreas anuales. Solo la "Iglesia de los bosques" ha podido preservar estas especies arbóreas. La Iglesia Etíope, como iglesia autóctona, tiene mucho que enseñar de sus conocimientos sobre el manejo sistemas forestales. Estos sistemas de conocimiento tradicional han sido muy efectivos para la conservación y preservación de los recursos naturales, ecosistemas locales y diversidad de especies arbóreas que ya hubieran desaparecido sin la presencia de la Iglesia. A pesar de estos hechos, la EOTC, que ha conservado una proporción significativa de los bosques en el país, no recibe el reconocimiento y apoyo merecido. 
La red extendida de parroquias llega a las comunidades marginadas y desarrolla una amplia gama de actividades. La Iglesia, a través de su Comisión de Desarrollo y Ayuda Inter-Ecclesial (Dicac), ha impulsado programas de ayuda que han desarrollado trabajos con comunidades afectadas por problemas como la pobreza, la sequía, el conflicto y el SIDA. Las parroquias promueven programas de desarrollo sostenible en sus jurisdicciones diocesanas, lo cual es un elemento clave para el desarrollo sostenible. En el año de 2002, Dicac manejó en cuatro diócesis programas de desarrollo, impulsó doce proyectos de desarrollo rural en el país, cuatro proyectos de seguridad alimentaria, seis proyectos para la educación sobre la cultura del agua y su abastecimiento, trabajó con proyectos de saneamiento ambiental e higiene, manejó cuatro centros de refugiados, nueve centros y sucursales del programa de SIDA, tres centros urbanos para refugiados, dos centros rurales de refugiados, tres programas internos de la Iglesia, y tres programas de la silvicultura.

Los bosques en propiedades de la Iglesia son considerados como sagrados ya que se ubican en predios de Dios. Desde 1986, la Iglesia ha promocionado campañas de silvicultura. Inicialmente, el trabajo consistió en establecer semilleros en escuelas, al igual que en iglesias y monasterios. En años recientes, el programa de reforestación ha implicado trabajo en las granjas de campesinos. Dicac se provee para sus programas de semillas gratuitas provenientes de los monasterios; ningún monasterio puede cortar un árbol sin el consentimiento de la oficina de la diócesis. La EOTC está haciendo un esfuerzo sostenido para enseñar al clero y la gente sobre la importancia de los árboles, destacando en sus proyectos y programas la necesidad de proteger los árboles existentes; y se induce a plantar y a cuidar de los árboles plantados y de las plantas autóctonas. Los bosques de un monasterio o parroquia son indicadores de las especies que se elegirán para los programas de la repoblación forestal, y son fuentes de conocimiento sobre la biodiversidad y modelos para el manejo sostenible del bosque. Muchas especies en extinción, como los monos colobus, babuinos, serpientes y una variedad de pájaros, que desaparecieron virtualmente de otros lugares de Etiopía, todavía subsisten en los bosques de las iglesias y de los monasterios.

Así, estas tradiciones plantean claras posibilidades para los programas futuros de conservación. La conservación de estas unidades de paisaje es el resultado de una filosofía que se plasma materialmente en iglesias y monasterios. Su realidad visible se constituye en una interesante alternativa para la vida parroquial del continente americano.

\section{IDEAS FINALES}

En general, se descubre que el cristianismo, a lo largo de los siglos, por lo menos en sus múltiples discursos temporales, registra importantes consideraciones en términos de la relación sociedad-naturaleza. Para el cristianismo, el mundo, en su plano del orden, debe orientarse hacia Dios. Un Dios que, según las escrituras y la historia, se ha revelado de manera muy concreta en tres personas: el Padre, el Hijo y el Espíritu Santo. El universo cristiano no es un universo antropocéntrico, ni biocéntrico. El universo cristiano es teocéntrico; es decir, la creación toda debería estar 
orientada hacia Dios. Ahora, el mundo natural es para los autores cristianos un soporte, una estructura básica y central en la constitución y el desarrollo de la imagen de Dios en el hombre y en la cristificación del Universo y la Tierra.

En el campo de las iglesias protestantes, las expresiones de cercanía entre el hombre, la naturaleza y la divinidad son extensas. Las iglesias luteranas, como el catolicismo romano, han generado una rica fundamentación ecoteológica que afirma que Dios se hace presente en la naturaleza y que la humanidad tiene afinidad por las criaturas de Dios. En síntesis, la ecoteología formula los siguientes enunciados: 1) hoy la creación de Dios está amenazada y experimenta una de las mayores crisis ecológicas de todos los tiempos, 2) los cristianos deben actuar con fuerza para solucionar los problemas ambientales, 3) la actual situación planetaria requiere una reconceptualización profunda de la teología cristiana (39).

Interesa tener en cuenta que la relación hombre-cosmos-naturaleza es una de las grandes constantes de la Biblia; las intervenciones históricas de Dios alcanzan siempre una resonancia cósmica que se expresa en el plano social, material y natural en el que se mueve el hombre. Dios se manifiesta en el mundo. Cada uno de los libros de la Biblia nos ofrece y nos entrega una particular enseñanza que puede ser leída desde una perspectiva ambiental.

En lo relativo a la relación hombre-cosmos-naturaleza, en la escritura sagrada, la vida y obra de mujeres y hombres en el cristianismo, sus oraciones, apotegmas, cantos, así como el patrimonio del pueblo judío, nos relatan y conectan con el mundo de la creación que se narra en el Génesis. La teología de la creación ofrece un terreno fértil para la acción ambiental desde una perspectiva cristiana, que tiene que concretarse en un diseño institucional potenciador de las relaciones del hombre con el mundo no humano y humano.

Vivimos tiempos caracterizados por la disolución, la ruptura social y política, así como por la alienación de la persona. Como lo ha puesto de manifiesto Lluís Duch (40), "las formas tradicionales de intercambio social han sido completamente sustituidas por regulaciones de tipo psicológico centradas en la salud y las vivencias del propio yo". La esfera religiosa y política que antaño orientara y regulara el comportamiento social, es cada vez menos capaz de "procurar la estabilidad social y la orientación de individuos y grupos sociales". Una sana espiritualidad, como dimensión constitutiva del hombre, en su inserción institucional-ecclesial tiene la potencia para articular un sentido de vida que nos permitiría superar la crisis de extinción que vive la humanidad. La revelación cristiana expresa valores ineludibles para un mundo que ha instaurado tremendas simplificaciones sobre el sentido de la existencia humana. La ilustración racionalista, que nada respeta en sus múltiples formas nihilistas, es una de las raíces del mal. Como nos indica V. Loosky (41), "bajo pretexto de instrucción, de 'luces', nos hemos sumergido en una oscuridad de ignorancia tal que hoy encontramos inconcebible todo aquello de que los antiguos tenían una noción tan clara".

(39) Hessel, 1992b, citado por Binde, ob. cit.

(40) L1. Duch, Antropología de la vida cotidiana, Madrid, Trotta, 2002, p. 16.

(41) Vladimir Loosky, A l'image et á la ressemblence de Dieu, Paris, Aubier, 1967. 
El problema central, por muy importante que sea el tema, no es el calentamiento del planeta, puesto que este es ya la expresión de un fenómeno natural de raíces culturales que habla del tremendo egoísmo e indiferencia que puede expresar el ser humano, especialmente el que se hace tremendamente rico y genera el hambre y la sed del pobre, para posteriormente "asistirlo" en caridad, o simplemente ignorarlo. El principal problema de la humanidad es la guerra que se libra en contra de la Verdad, Dios y su Iglesia y que tiene el efecto de inmovilizar al Pueblo de Dios, cerrándole los ojos ante el compromiso de liberación que se le exige en un plano comunitario. Hoy, el aparente éxito de esa guerra se evidencia cuando vemos lo dividida que está la Iglesia en la Tierra. Nuestra cultura contemporánea es un producto y expresión de la denominada cultura del riesgo, que puede entenderse como la expresión del declive de la cultura occidental y la crisis intelectual que padecemos; dicha crisis tiene la capacidad de activar todo un dispositivo cuasi terapéutico en la salvaguarda del planeta biótico y abiótico (;Salvemos la capa de ozono! ¡Salvemos las ballenas!), pero es incapaz, de manera seria, de transformar y eliminar las causas de la guerra, el hambre, la discriminación racial, la enfermedad, las políticas abortistas, de control natal, y la destrucción del planeta. Cualquier referencia a la verdad o al valor de la tradición judeocristiana, a un principio de autoridad, se diluye hoy en el discurso dominante del hacer por encima del ser, de la "construcción social de la realidad" por encima de cualquier principio trascendental previo a la experiencia. Hoy, todo hace parte de una de tantas narrativas sin identidad. Todo es relativo y la verdad -el kosmion- se define según las encuestas de opinión. Esos son los signos de nuestros tiempos, discursos relativistas y antiesencialistas, que ignoran la fuerza del metadiscurso de lo religioso, del transdiscurso simbólico que debe llevar a todos los pueblos a asumir el desafío de los valores siempre nuevos del Evangelio. Ahora bien, los signos de los tiempos presentes reclaman del cristiano hoy, la movilización de una potencia crítica que denuncie la demencia que se vive hoy en la tierra. Creo que es fundamental que todos los cristianos, en estos tiempos de calamidad planetaria, como nunca antes se habían vivido, entremos a profundizar en el sentido de la historia y del papel de la Iglesia en la historia. Como cristiano, criado en un ambiente cultural dominado por la tradición eclesial latina y romana, expreso mi desconcierto ante el panorama de dolor evitable, pero ya desencadenado, y que con mucha indiferencia y desconocimiento absoluto se expresa en círculos cristianos que ignoran el dolor, el sufrimiento y la destrucción del planeta, que se ha convertido en un gran campo de concentración y exterminio de millones de seres.

El Reino de Dios en su testimonio profético es una ciudad santa que aborrece la inequidad y la iniquidad. Es fundamental profundizar en la relación entre Iglesia, Reino de Dios, mundo y problemática ambiental. Las ciencias de la tierra lo que nos indican es que el tiempo es ya escaso para posibilitarle a millones de personas y de seres vivos unas condiciones mínimas de vida digna que les permitan contar con unos soportes de subsistencia tan sinfónicos como con los que contaron muchos de nuestros hermanos que nos precedieron en la fe. Hoy la vía de la unión, tiene mayores retos que los que vivió san Agustín o san Francisco. El mundo de ellos nunca estuvo amenazado a una escala planetaria. Nuestro mundo sufre una crisis global. Ese es el mayor pecado de la humanidad. La deificación del hombre, tan bellamente descrita por los Padres de la Iglesia, es decir nuestra santificación, no 
puede eludir un compromiso social y político. No es ya un asunto de hacer lo que se nos de la gana. Una espiritualidad burguesa es cómplice de la destrucción del planeta. Dios siempre ha reclamado del hombre una synergeia, una cooperación con él, que a través de esfuerzos constantes nos debe permitir generar buenas obras renunciando al mundo del poder, del consumo, de la indiferencia, de las pasiones desmedidas, la insensibilidad, el totalitarismo, la uniformidad, el egoísmo, la intriga, la mentira, la insolidaridad, la violencia y la lógica del dominio.

\title{
RESUMEN
}

En el artículo se identifican y reconocen algunas opciones que se pueden desarrollar en el cristianismo en relación con la problemática ambiental. Se aborda el dilema bíblico suscitado por interpretaciones antiecológicas y ecológicas. Con base en una lectura de la Biblia, de testimonios cristianos, y en una rememoria de estructuras institucionales, como la parroquia, se analiza el valor que tiene el mensaje cristiano en lo referido a la mitigación de la crisis ambiental.

Palabras clave: cristianismo, problemática ambiental, crisis ecológica, parroquia en América Latina, Iglesia etiope.

\begin{abstract}
This article identifies and recognizes some options that can be developed in Christianity in relation to the environmental problem. It starts by analyzing the biblical dilemma provoked by both ecological and anti-ecological interpretations. Based on a reading of the Bible, testimonies from Christians and with a re-memory of institutional structures, like the parish, the value of the Christian message for mitigating the environmental crisis is analyzed.
\end{abstract}

Key words: Christianity, Environmental problems, Ecological crisis, Parish, Latin America, Ethiopian Church. 